\title{
The Effect of Extrinsic Motivation on Housewife Actions in IVA Test in the Working Area of Community Health Center at Bandar Kalipah
}

\author{
Vani Olin Arysha ${ }^{1}$, Heru Santosa ${ }^{2}$, Sri Rahayu Sanusi ${ }^{2}$ \\ ${ }^{1}$ Master Student in Faculty of Public Health, Universitas Sumatera Utara, Medan, Indonesia \\ ${ }^{2}$ Lecturer in Faculty of Public Health, Universitas Sumatera Utara, Medan, Medan, Indonesia \\ Email: olin.vani@yahoo.com
}

\begin{abstract}
:
Cervical cancer is a cancer that attacks many women. The high number of cervical cancer sufferers in Indonesia is caused by only 5\% who screen for cervical cancer, because this disease does not cause symptoms and low awareness of women to check their health. Every woman of childbearing age should be motivated to do an IVA Test. The purpose of this study is to analyze the effect of extrinsic motivation on housewives actions in IVA Test. The design of this study is a case control with 36 samples in cases and controls. Processing data using chi square analysis with a 95\% significance level by calculating the odds ratio. The results showed that there was an influence of extrinsic motivation $(p=0,000)$ on the housewives actions in IVA Test. The results of the analysis showed that the OR 10.969 95\% CI (3.425-35.129) that did Possible IVA Test 10.9 is more effect than housewives who have extrinsic motivation.
\end{abstract}

Keywords:

extrinsic motivation; IVA; community health center

\section{Introduction}

Women are one important element in a family or community. Therefore, women's health, especially their reproductive health, is one of the important health problems. One of the reproductive organs of women who are susceptible to disease is the cervix and is called cervical cancer (Tambunan, 2016). Cervical cancer is a cancer that attacks many women. According to a 2013 report by the World Health Organization (WHO), cervical cancer is the second most common cancer case in women worldwide with a population of cancer deaths reaching 8.2 million cases. Every year more than 270,000 women die of cervical cancer, and more than $85 \%$ occur in developing countries.

In $85 \%$ of cases occur in developing countries. Indonesia is the fourth country with the highest incidence of cervical cancer in Southeast Asia. The annual incidence of cervical cancer in Indonesia is estimated at 20,998 cases, and the number of deaths from cervical cancer is 9,498 people (ICO, 2014). Based on data from the Ministry of Health of the Republic of Indonesia (2013) there are 100 cases per 100,000 population or 200,000 cases annually. And 70\% of cervical cancer cases handled in hospitals are in an advanced stage. Data from the North Sumatra Provincial Health Office (2015), cases of cervical cancer in North Sumatra were 283 cases, with the highest prevalence at $45-54$ years of age and $80 \%$ of cervical cancer cases were late stage and $75 \%$ ended in death.

The high rate of cervical cancer sufferers in Indonesia is caused by only $5 \%$ who screen for cervical cancer, because this disease does not cause symptoms and low awareness of women to check their health (Irianto, 2015). All diseases can be treated and treated quickly if early detection is done regularly so as to reduce the risk of mortality. If more and more women are 
accustomed to doing early detection, if the disease has contracted someone, it can be treated faster. Not doing early detection on a regular basis is the biggest factor causing an outbreak of cervical cancer in a person.

In an effort to tackle cancer, the Indonesian government conducted an early cancer detection program for Indonesian women for cervical cancer. The Indonesian government targets a minimum of $80 \%$ of women aged $30-50$ years to detect early cervical cancer every 5 years, where an early detection of cervical cancer by the Visual Inspection Method of Acetic Acid. For the year 2018 the implementation of early detection of cervical cancer the government is targeting coverage of $40 \%$ with a target age of 30-50 years of 14.9 million and for North Sumatra as many as 741,576 women of childbearing age (Permenkes, 2015).

From the results of the qualitative research of Larince (2017), the results obtained by the information provided to the community are the main causes of the low IVA test, causing the community to feel taboo, afraid to conduct inspections, and feel fine. And motivation to do IVA is very lacking. The lack of education about the dangers of cervical cancer, starting from how the signs, symptoms, causes and how early the disease, socialization is needed by cooperating with communities and religious leaders, in the implementation of IVA programs that attract interest in improving health.

Every woman of childbearing age should be motivated to do an IVA test. Motivation is the strength, drive, needs, pressure, and mechanisms which are intrinsic and extrinsic factors in making someone do something in response (Lestari, 2015). The intrinsic factor of the low coverage of IVA test is due to the low awareness of women of childbearing age couples doing early detection of cervical cancer, where most women do not consider screening by IVA test an important need for health (Larince, 2017).

One extrinsic factor that motivates women of childbearing age couples to do an IVA test is the existence of support from their husbands. Family support, especially the husband's role in increasing the interest of the wife to conduct an early detection check with the IVA Test method. The mistaken view of early detection of cervical cancer will have an effect on the opportunities and choices for wives to gain control over their reproductive health which can cause housewives to have a greater risk of experiencing reproductive health disorders (Burn, 2016).

From the results of an initial survey conducted by researchers on 10 housewives who visited Community Health Center at Bandar Kalipah, generally the reasons for the mothers not wanting to do an IVA test included that they thought they did not need to do the test because of their good sexual behavior which did not change partners, besides that there is a feeling of shame because they have to be examined by their sex organs. Feeling taboo and afraid that the results of the test will be abnormal. Based on the initial survey conducted in Community Health Center at Bandar Kalipah, the number of IVA tests is still relatively low when compared to the national coverage target of IVA tests at Community Health Center. The number of IVA test visits in 2016 was 530 people $(4.1 \%)$ mentioned that 25 people detected positive IVA results and were referred. From IVA visit data in 2017 as many as 338 people (2.6\%), it was mentioned that 4 people were detected as positive IVA who were suspected of cervical cancer and were referred to Murni Teguh Hospital.

This study aims to analyze the effect of extrinsic motivation on the housewives actions on visual inspection of acetic acid (IVA Test) as an early detection of cervical cancer in the working area of Community Health Center at Bandar Kalipah. 


\section{Research Method}

Observational design with case control studies is often also called a retrospective study. This research was conducted in the working area of Community Health Center at Bandar Kalipah. The population in this study were 7,894 women of childbearing age consisting of 2 types: case population and control population. The case population is a housewife who did an IVA Test in 2017 which amounted to 338 people and the control population was a housewife who did not do an IVA Test amounting to 7,556 people.

The sample in each case and control group was 36 people with hypothesis testing for the proportion of a single population using the Lameshow formula. The sampling technique uses purposive sampling technique. Data collection was carried out using a questionnaire containing statements that had been validated and reliably. Measurement of the independent variables namely extrinsic motivation includes husband's support, environment and information media.

To find out the relationship between extrinsic motivation and housewife in the IVA test Chi square test was used at a 95\% confidence level $(\mathrm{p}<0.05)$. Odd ratio (OR) calculation is used, which is the ratio of exposure between groups of cases to the control group to see the estimated risk of outcome. Confedence Interval Estimation (CI) is set at a 95\% confidence level. If the bivariate analysis calculation results show a significant relationship $(p<0.05)$, it will be further analyzed using multiple logistic regression analysis.

\section{Result and Discussion}

\subsection{Characteristics of Respondents in the Working Area of Community Health Center at Bandar Kalipah}

Characteristics of respondents based on age more at the age of 30-40 years on housewife who did IVA Test of $66.7 \%$. In the control group based on the age of 30-40 years and 41-50 years the same in the housewife who did not do the IVA Test by $50 \%$. Characteristics of respondents based on religion are predominantly Muslim in the case group by $77.8 \%$ and the control group by $72.2 \%$.

Characteristics of respondents based on ethnicity were more Batak in 36.1\% of the case group and $52.8 \%$ in the control group. Characteristics of respondents based on the average educational status of highly educated namely high school education in the case group by $52.8 \%$ and in the control group by $61.1 \%$. Characteristics of respondents based on the number of children almost equally have the number of children $\leq 3$ children, namely in the case group by $75.0 \%$ and the control group by $86.1 \%$. Characteristics of respondents based on age of first time having sex in the case group more having sex for the first time at age $>20$ years by $55.6 \%$ and in the control group having more sex for the first time at age $\leq 20$ years by $69.4 \%$.

\section{Extrinsic Motivation}

Table 1. The results of the cross tabulation between extrinsic motivation and housewife action on the IVA Test

\begin{tabular}{lccccccc}
\hline Extrinsic Motivation & $\begin{array}{c}\text { Doing the IVA } \\
\text { Test }\end{array}$ & \multicolumn{9}{c}{$\begin{array}{c}\text { Not Doing the } \\
\text { IVA Test }\end{array}$} & OR & 95\% CI & $p$ \\
\cline { 2 - 5 } & $\mathbf{n}$ & $\mathbf{0}$ & $\mathbf{N}$ & $\mathbf{\%}$ & & & \\
\hline a. Strong Motivation & 23 & 82,1 & 5 & 17,9 & 10,9 & $3,425-35,129$ & 0,000 \\
b. Medium Motivation & 13 & 29,5 & 31 & 70,5 & 69 & & \\
Total & $\mathbf{3 6}$ & & $\mathbf{3 6}$ & & & & \\
\hline
\end{tabular}


Table 1 shows that extrinsic motivation with a strong category became the urge of respondents to do an IVA Test of $82.1 \%$. While the extrinsic motivation with the moderate category in housewives did not do an IVA Test of $70.5 \%$. This table also produces a value of $\mathrm{p}$ $<0.05$ which is 0.000 which means there is influential extrinsic motivation with the actions of housewives doing an IVA Test. The results of data analysis showed an OR value with a $2 \times 2$ table showing an OR value of 10.969 with $95 \%$ CI 3,425-35,129. The OR value explains that conducting an IVA Test is likely to be 10.9 more influential than housewives who have extrinsic motivation.

The results of research according to Holmes et.al (2005), health seeking behavior that is influenced by extrinsic motivation refers to various things that humans do to prevent disease and to detect disease. The assumption of researchers, motivation to conduct IVA test can arise in themselves due to the desire to be free and the interaction with other people and the environment. Someone who does work outside the home will interact with others and the environment can add insight and knowledge so that motivates someone. Respondents who are only housewives do not work and a lot of time is spent at home, but a lot of information can be obtained from print, electronic, family, and health workers in the surrounding environment.

\subsection{The Most Dominant Risk Factor Affects Housewife's Actions}

The variables analyzed in the multivariate model are extrinsic motivation in the form of husband, environment, and media support. The results of the multivariate model analysis can be seen in the following table:

Table 2. Results of Multiple Logistic Regression Analysis

\begin{tabular}{|c|c|c|c|c|c|}
\hline \multirow{2}{*}{ Variable } & \multirow{2}{*}{ B } & \multirow{2}{*}{$\boldsymbol{P}$} & \multirow{2}{*}{$\operatorname{Exp}(B)$} & \multicolumn{2}{|c|}{$95 \% \mathrm{CI}$} \\
\hline & & & & Lower & Upper \\
\hline Husband's Support & 2,458 & 0,003 & 11,685 & 2,264 & 60,299 \\
\hline Environment & 1,774 & 0,026 & 5,897 & 1,239 & 28,063 \\
\hline Media & 0,480 & 0,554 & 1,616 & 0,330 & 7,909 \\
\hline Constanta & $-8,686$ & 0,000 & & & \\
\hline
\end{tabular}

The results of the analysis in table 2 prove that extrinsic motivation in the form of husband's support is the most dominant variable affecting the actions of housewives on the IVA Test because it has a p score $=0.003$ with $\operatorname{Exp}$ (B) 11,685. The OR value explains that the housewife action for conducting an IVA Test is 11 times more likely to come from an housewife who has a husband's support than one who does not have a husband's support.

Research conducted by Atun (2017) states that family support plays an important role in increasing the interest or willingness of women to conduct IVA Tests. The family, especially the husband, is a strong motivator when always accompanying and reminding mothers to do an IVA test. The role of the husband as a decision maker will be

greatly affect the mother's behavior in conducting an IVA Test. Agree with research conducted by Wahyuni (2013) which concluded that husband's support is the factor that most influences early detection behavior with cervical cancer with a value of $\mathrm{p}=0.01$ and OR 3.05, which means husband's support 3.05 times affects behavior in detection premature cervical cancer. 


\section{Conclusion}

It was concluded that extrinsic motivation yields $\mathrm{p}<0.05$, which is 0.000 , which means that there is an influence of extrinsic motivation with the actions of housewives who test IVA Test with an OR score of 10,969 with 95\% CI 3,425-35,129. Extrinsic motivation in the form of husband support is the most dominant variable effecting the actions of housewives on the IVA test because it has $\mathrm{p}=0.003$ with $\operatorname{Exp}(\mathrm{B}) 11,685$.

\section{Acknowledgment}

On this occasion the authors convey their respect and gratitude to the health center staff and mothers who do iva tests that are willing to support the implementation of this research.

\section{References}

Burns, A., Lovich, R., Maxwell, J., Shapiro, K., 2016. Pemberdayaan Wanita dalam Bidang Kesehatan (Terjemahan dr. Faizah Jasin ), Indonesia: ANDI.

Dinas Provinsi Sumatera Utara, 2015. Data Kejadian Kanker Serviks Provinsi Sumatera Utara.

Dinas Kesehatan Deli Serdang, 2015. Rekapitulasi Deteksi Dini Kanker Leher Rahim dan Kanker Payudara dengan Metode IVA Test dan CBE.

ICO (Information Centre on HPV and Cancer),2014.http://www.hpvcentre.net/statistics/report/IND/pdf.

Irianto, Koes. 2015. Kesehatan Reproduksi, Bandung: Alfabeta.

Kemenkes, 2013. Pencegahan Kanker Payudara dan Kanker Leher Rahim, Jakarta: Ditjen PP\&PL.

Larince, R.F., Fikarwin, Z., Frida, L., 2017. Rendahnya Cakupan Pemeriksaan IVA di Puskesmas Binjai Estate Tahun 2017. Jurnal Ilmiah Kohesi: Vol.1 No.3 Oktober 2017, ISSN: 25795872.

Lestari, T., 2015. Kumpulan Teori untuk Kajian Pustaka.Yogyakarta: NuMed.

Peraturan Menteri Kesehatan Republik Indonesia. 2015. Nomor 34 tahun 2015 Penanggulangan Kanker Payudara dan Kanker Leher Rahim.

Profil Kesehatan Indonesia., 2016. Kementerian Kesehatan Republik Indonesia.

Tambunan, R., 2016. Faktor-Faktor yang Mempengaruhi Wanita yang Sudah Menikah untuk Melakukan IVA di Puskesmas Mulyorejo Kec. Sunggal Kab. Deli Serdang. Universitas Sumatera Utara: Tesis.

WHO. 2013. Prevention of cervical cancer through screening using visual inspection with acetic acid (VIA) and treatment with cryotherapy. 